\title{
DESAIN PENGEMBANGAN KURIKULUM MADRASAH INKLUSIF DENGAN PENDEKATAN HUMANISME RELIGIUS
}

\author{
Oleh \\ Uswatun Chasanah ${ }^{1}$ \\ Email: uswatun_chasanah9@yahoo.com
}

\begin{abstract}
Discrimination in education should be abolished. Every child is entitled to a proper education in accordance with the type of needs and talents of interest as mandated. Through an inclusive madrasah model with its learning model bringing together regular and special needs learners in an educational environment, the educator can realize the values of humanism in the learning process. The manifestation of humanism values can be set forth in the design of inclusive madrasah curriculum development with the approach of religious humanism consisting of four models of curriculum development is duplication model, modification, substitution, and omission. The four curriculum models are described in the Lesson Plan and Individual Learning Program (PPI) designed by internalizing the values of religious humanism through modeling, modeling and habituation activities in the learning process in the classroom or outside the classroom.
\end{abstract}

Keywords: inclusive madrasah curriculum, humanism, religious

\section{Pendahuluan}

Al-Qur'an adalah penyempurna kitab-kitab agama samawi yang mengatur segala aspek kehidupan manusia berbangsa dan bernegara, termasuk mengatur hak asasi manusia dalam memperoleh pendidikan. Sebagaimana yang tertuang dalam surat an-Nuur ayat 61 dijelaskan bahwa tidak ada bedanya antara orang-orang yang cacat dengan yang normal dalam pergaulan hidup bermasyarakat. Selain Surat an-Nuur ayat 61, dalam Surat Abasa ayat 1 sampai 4 juga dijelaskan bahwa kita tidak boleh

${ }^{1}$ Dosen Fakultas Tarbiyah dan Keguruan, Universitas Islam Negeri Sunan Ampel 
membeda-bedakan atau bermuka masam ketika ada seseorang yang datang kepada kita untuk memperoleh ilmu atau pengajaran. ${ }^{2}$

Kedua ayat di atas, dapat dijadikan indikator bahwa Islam memberikan perhatian yang amat besar terhadap penyelenggaraan pendidikan inklusif. Islam tidak membedakan antara peserta didik yang normal dengan peserta didik yang berkebutuhan khusus dalam memperoleh layanan pendidikan. Islam memiliki dasar landasan yang kuat dalam pengembangan pendidikan inklusif. Sebagaimana sesuai dengan pesan-pesan yang terkandung dalam ayat-ayat di atas yaitu larangan bagi kita untuk membeda-bedakan kondisi jasmani, mental, bakat, minat dan kemampuan seseorang. Selain itu, kita dianjurkan untuk selalu terbuka menerima dan tidak mengkhawatirkan segala macam kondisi cacat tubuh seseorang yang akan menuntut ilmu di suatu lembaga pendidikan, terutama di lembaga pendidikan Islam atau madrasah.

Berkaitan dengan konsep pengembangan madrasah inklusif, kebijakan pendidikan inklusif di Kementerian Agama belum menjadi prioritas utama dalam pengembangan madrasah, karena secara legal Kementerian Agama Republik Indonesia belum mengatur secara oprasional tentang penyelenggaraan pendidikan inklusif di madrasah, akan tetapi dalam Peraturan Menteri Agama Nomor 90 Tahun 2013 tentang penyelenggaraan madrasah dijelaskan bahwa tiap jenjang pendidikan di madrasah harus memberikan akses pendidikan bagi anak berkebutuhan khusus.

Oleh sebab itu, dalam tulisan ini teori-teori tentang madrasah inklusif penulis adopsi dari dengan Peraturan Menteri Pendidikan Nasional No. 70 Tahun 2009 tentang Pendidikan Inklusif Bagi Peserta Didik yang Memiliki Kelainan dan Memiliki Potensi Kecerdasan dan/Bakat Istimewa dan pada Peraturan Gubenur Jawa Timur No.6 Tahun 2011 Tentang Penyelenggaraan Pendidikan Inklusif Provinsi Jawa Timur.

\section{Pengembangan Kurikulum}

Pengertan kulikulum berasal dari bahasa Latin yaitu "curriculum" yang artinya yaitu a running course, sedangkan dalam bahasa Perancis bermakna

${ }^{2}$ Syamsul Huda Rohmadi, Kurikulum Berbasis Inklusif di Madrasah (Landasan Teori dan Desain Pembelajaran Prespektif Islam), digilib.uinsby.ac.id 
courier yang artinya to run atau dalam bahasa Indonesia berarti berlari. Dunia pendidikan kemudian mengadopsi istilah pengertian kurikulum tersebut untuk mendefinisikan kurikulum sebagai sejumlah mata pelajaran yang harus dipelajari oleh peserta didik untuk menyelesaikan suatu jenjang pendidikan dan mendapatkan surat tanda kelulusan atau ijazah. ${ }^{3}$ Definisi kurikulum di atas menekankan pada sejumlah isi pelajaran yang direncanakan sekolah secara tertulis.

Dalam perkembangannya, pengertian kurikulum mengalami perluasan makna yang tidak hanya sebatas sejumlah pelajaran yang harus ditempuh pada tiap jenjang pendidikan, akan tetapi kurikulum dimaknai sebagai semua kegiatan atau pengalaman yang direncanakan (kurikulum formal) maupun tidak direncanakan (hidden curriculum) oleh sekolah, baik yang diselenggarakan di sekolah maupun di luar sekolah, atau dalam Undang -Undang Republik Indonesia Nomor 20 Tahun 2003 Tentang Sistem Pendidikan Nasional, kurikulum didefinisikan sebagai seperangkat rencana dan pengaturan mengenai tujuan, isi, dan bahan pelajaran serta cara yang digunakan sebagai pedoman penyelenggaraan kegiatan pembelajaran untuk mencapai tujuan pendidikan tertentu. ${ }^{4}$

Merujuk pada pengertian kurikulum yang tertuang di dalam UndangUndang Republik Indonesia Nomor 20 Tahun 2003 Tentang Sistem Pendidikan Nasional, maka komponen kurikulum meliputi tujuan, isi atau bahan pelajaran dan cara pembelajaran yang meliputi metode pembelajaran, sarana, dan evaluasi.

Komponen tujuan merupakan suatu hal yang sangat penting dalam proses pembelajaran. Tujuan pembelajaran secara sistematis meliputi tujuan pendidikan nasional, tujuan institusional, tujuan kurikuler, tujuan instruksional (umum dan khusus). ${ }^{5}$ Tujuan pendidikan nasional

${ }^{3}$ Abdullah Idi, Pengembangan Kurikulum Teori dan Praktek (Jakarta: Gaya Media Pratama, 1999), 3-4: Zumrotul Mukaffa dkk, Pengembangan Model Madrasah Inklusif (Studi atas Kesiapan dan Model Pengembangan Kurikulum Madrasah Inklusif MI AlHidayah Margorejo Surabaya) EDUKASIA: Jurnal Penelitian Pendidikan Islam, Vol 12, No 1 (2017). http://digilib.uinsby.ac.id

${ }^{4}$ Undang-Undang Republik Indonesia Nomor 20 Tahun 2003 Tentang Sistem Pendidikan Nasional, 4. http://kelembagaan.ristekdikti.go.id/wp-

${ }^{5}$ Abdullah Idi, Pengembangan Kurikulum, 13. 
merupakan tujuan tertinggi yang tertuang dalam Undang-Undang Republik Indonesia Nomor 20 Tahun 2003 Tentang Sistem Pendidikan harus dicapai dalam pelaksanaan pendidikan yaitu mengembangkan kemampuan dan mewujudkan watak sertaa peradaban bangsa yang bermartabat dalam rangka mencerdaskan kehidupan bangsa, bertujuan untuk berkembangbya potensi peserta didik agar menjadi manusia yang beriman dan bertakwa kepada Tuhan Yang Maha Esa, berakhlak mulia, sehat, berilmu, cakap, kreatif, mandiri, dan menjadi warga Negara yang demokratis serta bertanggung jawab. ${ }^{6}$

Tujuan institusional yaitu tujuan yang dikembangkan oleh suatu lembaga pendidikan misalnya tujuan lembaga pendidikan SD/MI, SMP/MTS, SMA/MA yang merupakan tidak lanjut dari tujuan pendidikan nasional. Tujuan kurikuler adalah tujuan yang dirumuskan dalam suatu bidang studi atau mata pelajaran. Tujuan intruksional yaitu tujuan yang dirumuskan dalam menyusun perancanaan pembelajaran dan harus dicapai dalam setiap penyelenggaraan proses pembelajaran ${ }^{7}$

Komponen isi atau bahan pelajaran merupakan komponen yang didesain dalam rangka mendukung tercapainya tujuan pendidikan yang terdiri dari 4 tujuan sebagaimana teruraikan di atas. Pengembangan isi atau bahan ajar didesain berdasarkan kompetensi inti dan kompetensi dasar yang tertuang dalam Peraturan Menteri Pendidikan Nasional tentang Kompetensi Inti dan Kompetensi Dasar. Selain itu, bahan ajar juga didesain dengan memperhatikan jenjang pendidikan dan karakteristik peserta didik dan kebutuhan lokal serta perkembangan ilmu dan teknologi.

Komponen metode merupakan cara yang digunakan oleh seorang pendidik untuk menyampaikan isi atau materi pelajaran sehingga tujuan pembelajaran dapat tercapai. Metode pembelajaran dipilih berdasarkan karakteristik materi dan karakteristik peserta didik. Deskripsi tentang implementasi metode dalam sebuah kurikulum diurakan dalam desain perencanaan pembelajaran secara sistematis berdasarkan sintaks sebuah strategi pembelajaran yang dipilih oleh seorang guru. Begitu juga dengan komponen evaluasi teruraikan dalam sebuah desan perencanaan

\footnotetext{
${ }^{6}$ Undang-Undang Republik Indonesia, Nomor 20 Tahun 2003,

${ }^{7}$ Abdullah Idi, Pengembangan Kurikulum, 14-16.
} 
pembelajaran. Evaluasi pembelajaran harus mengukur kompetensi dan indikator yang akan dicapai dalam proses pembelajaran. Pada kurikulum 2013, evaluasi harus mengukur domain sikap spiritual, sikap sosial, pengetahuan dan keterampilan. Instrumen evaluasi harus dipilih berdasarkan domain yang akan diukur dalam sebuah proses pembelajaran. Dalam kurikulum 2013, standar penilaian pendidikan diatur dalam Peraturan Menteri Pendidikan dan Kebudayaan Republik Indonesia Nomor 23 Tahun 2016 tentang Standar penilaian Pendidikan.

Evaluasi domain sikap merupakan kegiatan untuk mendapatkan informasi berkaitan dengan perkembangan perilaku peserta didik selama proses pembelajaran, baik pembelajaran di kelas maupun di luar kelas. Evaluasi sikap harus diselenggarakan secara berkelanjutan oleh seoraang guru. Evaluasi domain pengetahuan bertujuan untuk mengetahui sejauhmana peserta didik menguasai materi pembelajaran. Sedangkan evaluasi doamian keterampilan bertujuan untuk mendeskripsikan kemampuan peserta didik dalam mengaplikasikan pengetahuan yang telah dikuasai dalam suatu project yang diberikan oleh guru. ${ }^{8}$

Komponen sarana dan prasarana dalam pengembangan kurikulum merupakan sarana pendukung dalam pelaksanaan proses pembelajaran. Dalam Peraturan Menteri Pendidikan Nasional Republik Indonesia Nomor 24 Tahun 2007 dijelaskan bahwa standar sarana dan prasaranaa mencakup kriteria minimum sarana dan kriteria minimum prasarana. ${ }^{9}$

\section{Madrasah Inklusif}

Pengertian madrasah secara etimologi berasal dari bahasa Arab yang merupakan isim makan dari kata "darasa" yang berarti belajar. Berdasarkan pengertian tersebut, madrasah berarti tempat yang difungsikan sebagai untuk menyelenggarakan proses belajar mengajar secara formal bagi peserta didik yang beragama Islam. ${ }^{10}$ Madrasah sebagai salah satu lembaga

${ }^{8}$ Peraturan Menteri Pendidikan dan Kebudayaan Republik Indonesia Nomor 23 Tahun 2016 tentang Standar penilaian Pendidikan, 3.

${ }^{9}$ Peraturan Menteri Pendidikan Nasional Republik Indonesia Nomor 24 Tahun 2007 tentang Standar Sarana dan Prasarana SD/MI/SMP/MTs, SMA/ MA, 2.

${ }^{10}$ Hans Wehr, A Dictionary of Modern Written Arabic. ed. J Milton Cowan, (Beirut: Maktabah Lubnan, 1980), 278; 
pendidikan Islam mempunyai peran penting dalam mencerdaskan manusia (peserta didik), menghilangkan ketidaktahuan, serta mengembangkan keterampilan peserta didik sesuai dengan bakat dan minatnya. Dalam Peraturan Menteri Agama Republik Indonesia Nomor 90 Tahun 2013 tentang Penyelenggaraan Pendidikan Madrasah dijelaskan bahwa madrasah adalah satuan pendidikan formal dalam binaan Kementerian Agama yang menyelenggarakan pendidikan umum dan kejujuran dengan kekhasan agama Islam yang mencakup tiga jenjang pendidikan yaitu jenjang pendidikan anak usia dini atau yang dikenal dengan Raudhatul Athfal, jenjang pendidikan dasar yang dikenal dengan Madrasah Ibtidaiyah dan Madrasah Tsanawiyah dan jenjang pendidikan menengah atau yang dikenal dengan Madrasah Aliyah dan Madrasah Aliyah Kejuruan ${ }^{11}$

Ketiga jenjang pendidikan di madrasah dalam penyelenggaraannya wajib menyediakan layanan akses pendidikan bagi peserta didik berkebutuhan khusus sebagaimana yang tertuang dalam Peraturan Menteri Agama Republik Indonesia Nomor 90 Tahun 2013 tentang Penyelenggaraan Pendidikan Madrasah pasal 14, 16 dan 18. Merespon kebijakan tersebut, maka dalam perkembangan madrasah inklusif dalam tulisan ini mengadopsi istilah-istilah yang dikembangkan dalam Permendikbud Nomor 70 tahun 2009 tentang Pendidikan, Inklusif Bagi Peserta Didik yang Memiliki Kelainan dan Memiliki Potensi Kecerdasan dan/atau Bakat Istimewa yaitu madrasah inklusif

Madrasah inklusif yaitu satuan pendidikan dibawah binaan Kementerian Agama yang menyelenggarakan pendidikan formal dan kejuruan dengan kekhasan agama Islam dengan memberikan layanan pendidikan bagi anak reguler dan anak berkebutuhan khusus untuk

Atabik Lutfi, Ahmad Zuhdi Muhdlor, Kamus Kontemporer Arab-Indonesia, (Yogyakarta: Yayasan Ali Maksum Ponpes Krapyak Yogyakarta, 1997), 891; Idris Thaha, al-Madrasah dalam Ensiklopedi Islam, Vol. 3, (Jakarta: Ichtiar Baru van Hoeve, 2005), 205; A. Fatah Yasin, Dimensi- Dimensi Pendidikan Islam (Malang: UIM Malang Press, 2008), 257.

${ }^{11}$ Peraturan Menteri Agama Republik Indonesia Nomor 90 Tahun 2013 tentang Penyelenggaraan Pendidikan Madrasah, 9. 
bersama-sama mengikuti proses pembelajaran dalam satu lingkungan pendidikan yang sama. ${ }^{12}$

\section{Peserta Didik, Pendidik, dan Tenaga Kependidikan di Madrasah Inklusif}

Dalam Permendikbud Nomor 70 tahun 2009 tentang Pendidikan Inklusif Bagi Peserta Didik yang Memiliki Kelainan dan Memiliki Potensi Kecerdasan dan/atau Bakat Istimewa dijelaskan bahwa peserta didik pada lembaga pendidikan yang menyelenggarakan program inklusif terdiri dari peserta didik reguler atau normal dan peserta didik yang berkebutuhan khusus yang meliputi: tunanetra, tunarungu, tunawicara, tunagrahita, tunadaksa, tunalaras, anak berkesulitan belajar, lamban belajar, autis, anak memiliki gangguan motorik, korban penyalahgunaan narkoba, obat terlarang, tunaganda dan kelainan lainnya. ${ }^{13}$ Peserta didik yang tergolong berkebutuhan khusus memiliki hambatan belajar yang bervariasi dan desain pembelajaran disesuaikan dengan kelainan yang dialami peserta didik.

Adapun tenaga pendidik dalam madrasah inklusif meliputi: guru kelas $^{14}(\mathrm{SD} / \mathrm{SM})$, guru wali kelas ${ }^{15}$, guru mata pelajaran ${ }^{16}$, guru pendidik khusus ${ }^{17}$, guru bantu, ${ }^{18}$ tenaga ahli19, guru bimbingan dan penyeluhan. ${ }^{20}$

${ }^{12}$ Zumrotul Mukaffa dkk, Pengembangan Model Madrasah Inklusif, 8.

${ }^{13}$ Permendikbud Nomor 70 tahun 2009 tentang Pendidikan, Inklusif Bagi Peserta Didik Yang Memiliki Kelainan dan Memiliki Potensi Kecerdasan Dau/ atau Bakat Istimewa, 3 .

${ }^{14}$ Guru kelas adalah guru yang mengajar di SD/MI dan bertanggung jawab mengajar semua mata pelajaran di SD/MI kecuali pendidikan agama dan olah raga. Lihat. Direktorat Pembinaan Sekolah Luar Biasa, Pedoman Manajemen Sekolah Inklusif Pendidikan Dasar (Jakarta, Departemen Pendidikan Nasional, 2008), 20.

${ }^{15}$ Guru wali kelas adalah guru yang mendapat tugas tambahan sebagai pengelola manajemen kelas. Lihat. Ibid., 20

${ }^{16}$ Guru mata pelajaran adalah guru yang bertanggung jawab melaksanakan pembelajaran pada mata pelajaran tertentu. Lihat. Ibid., 20.

${ }^{17}$ Guru pendidik khusus adalah guru yang berkualifikasi sarjanah (S1) pendidikan luar biasa (ortopedagog) yang memiliki tugas dan fungsi sebagai pendamping dan bekerja sama dengan guru kelas atau guru bidang studi dalam melakukan assesmen, menyusun program pengajaran individual dan memberikan layanan pendidikan khusu bagi peserta didik berkebutuhan khusus pada madrasah inklusif. Adapun materi pembelajaran yang menjadi tanggung jawab guru pendidik khusus yaitu materi layanan pembelajaran pra- 
Sedangkan tenaga kependidikan pada madrasah inklusif meliputi: pengelola satuan pendidikan, pustakawan, laboran, dan teknisi sumber belajar. $^{21}$

\section{Model Pembelajaran di Kelas Inklusif}

Dalam tulisan Umi Muzayanah yang berjudul "Penyelenggaraan Pendidikan Inklusif Pada Madrasah Ibtidaiyah (MI) Keji Ungaran Jawa Tengah" dijelaskan bahwa model pembelajaran di lembaga penyelenggara pendidikan inklusif diantaranya yaitu: pertama, model reguler/inklusif penuh yaitu model pembelajaran yang didesain dengan menyatukan anak reguler dan anak berkebutuhan khusus dalam satu kelas yang sama dan model kurikulum yang sama. Kedua, model reguler dengan cluster yaitu desain pembelajaran di sekolah inklusif yang menyatukan peserta didik reguler dengan peserta didik berkebutuhan khusus dalam satu ruangan kelas reguler namun dalam kelompok khusus. Ketiga, model reguler dengan pull out yaitu model pembelajaran di kelas inklusif dengan menyatukan peserta didik reguler dengan peserta didik berkebutuhan khusus dalam satu kelas reguler yang sama, akan tetapi pada waktu tertentu peserta didik berkebutuhan khusus pindah pada ruang sumber untuk mendapatkan pelayanan khusus dari guru pendidik khusus. Keempat, model pembelajaran reguler dengan cluster dan pull out yaitu model pembelajaran di kelas inklusif dengan menyatukan peserta didik reguler dan peserta didik berkebutuhan khusus dalam kelas reguler yang sama dalam kelompok khusus, pada waktu tertentu peserta didik dipindahkan ke ruang sumber untuk mendapatkan pelayanan khusus sesuai dengan kelainannya. Kelima model kelas khusus dengan berbagai

akademik, layanan kekhususan, dan layanan pendidikan bagi ABK yang mengalami hambatan dalam pembelajara akademik. Lihat. Ibid., 19-20.

${ }^{18}$ Guru bantu adalah guru pendamping dalam proses pembelajaran.

${ }^{19}$ Tenaga ahli adalah tenaga professional pada disiplin ilmu tertentu yang relevan dengan kebutuhan pembelajaran pada madrasah inklusif yang antara lain yaitu pedagog, psikolog, psikiater, dokter spesialis, serta rohaniwan, dan ahli gizi, .Lihat. Ibid., 20.

${ }^{20}$ Guru bimbingan dan konseling adalah guru yang bertanggung jawab untuk menemukan solusi atas mmasalah yang dihadapi oleh peserta didik berkebutuhan khusus. Lihat. Ibid., 21.

${ }^{21}$ Ibid., 9. 
pengintegrasian yaitu model pembelajaran yang memberikan pelayanan pendidikan kepada peserta didik berkebutuhan khusus pada kelas-kelas khusus di sekolah inklusif, akan tetapi pada waktu tertentu menyatukan peserta didik berkebutuhan khusus pada kelas reguler. Keenam, model kelas khusus yaitu desain model pembelajaran yang memberikan pelayanan kepada peserta didik pada kelas khusus pada sekolah reguler.22

\section{Humanisme Religius}

Humanis adalah sebuah doktrin yang mangandung ajaran yang mengutamakan pada kepentingan manusia dalam hidupnya. Pengikut aliran ini menginginkan dalam hidupnya selalu berlandaskan pada asas kemanusiaan.23 Dalam prespektik filsafat agama, aliran humanisme adalah cabang etika yang mulai ada sejak abad ke-16 bersamaan dengan adanya reformasi di Kristen. Aliran humanisme mulai bangkit dengan adanya gagasan yang dikumandangkan oleh Erasmus yaitu hak asasi manusia sebagai makhluk individu untuk menentukan nasibnya sendiri. Gagasan yang Erasmus ungkapkan mendapat banyak kritikan dari para teolog Kristen. ${ }^{24}$

Humanisme religius merupakan konsep keagamaan yang memposisikan manusia sebagai manusia pada hakikatnya dan upaya humanisasi ilmu-ilmu dengan tetap memperhatikan tanggung jawab bahlum minallah dan hablum minannas. Konsep humanisme religius ini jika diterapkan dalam proses pembelajaran akan berfokus pada akal sehat, kemandirian dan tanggung jawab, pluralisme, kontektualisme dan keseimbangan reward dan punishment ${ }^{25}$. Konsep memanusiakan manusia

${ }^{22}$ Umi Muzayanah yang berjudul "Penyelenggaraan Pendidikan Inklusif Pada Madrasah Ibtidaiyah (MI) Keji Ungaran Jawa Tengah" PENAMAS “Jurnal Keagamaan dan Kemasyarakatan” Volume 29, Nomor 2 Juli-September 2016, 215.

${ }^{23}$ Yushinta Eka Farida, "Humanisme Dalam Pendidikan Islam” Jurnal Tarbawi Vol. 12 No. 1. Januari-Juni 2015, 108.

${ }^{24}$ Husna Amin, "Aktualisasi Humanisme Relegius Menuju Humanisme Spiritual Dalam Bingkai Filsafat Agama” Jurnal Substantia Vol. XV, No. 1 April 2013, 68.

25 Abdurrahman Mas'ud, Menggagas Format Pendidikan Nondikotomik (Humanisme Relegius Sebagai Peradigma Pendidikan Islam) (Yogyakarta: Gama Media, 2002), 193. 
dalam ajaran Islam tertuang dalam al-Qur'an di antaranya dalam Qur'an Surat Al-Isra ayat 70:

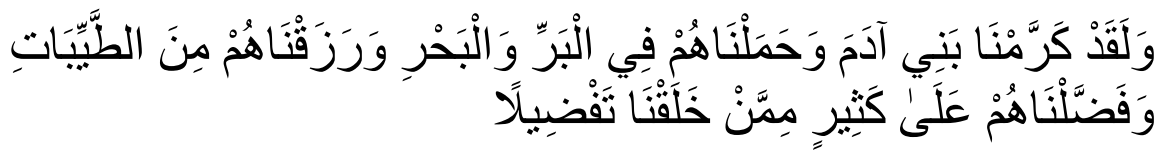

"Dan sesungguhnya telah Kami muliakan anak-anak Adam, Kami angkut mereka di daratan dan di lautan,Kami beri mereka rezki dari yang baik-baik dan Kami lebihkan mereka dengan kelebihan yang sempurna atas kebanyakan makhluk yang telah Kami ciptakan". 26

Berdasarkan ayat di atas bahwa sebelum aliran humanisme lahir dalam Islam terlebih dahulu mengajarkan kepada pengikutnya untuk memanusiakan manusia. Allah sangat memuliakan manusia di antara makhluk Allah lainnya. Manusia lahir dengan dibekali kodrat yang cukup sempurna yang berupa cipta, rasa, dan karsa. Melalui cipta, rasa, dan karsa, manusia akan mampu mendapatkan nilai-nilai kebenaran, keindahan dan kebaikan yang terkandung dalam segala realitas yang ada di muka bumi. Nilai kebenaran, keindahan, dan kebaikan jika dijadikan sebagai landasan hidup maka manusia di dalam hidupnya akan mampu mewujudkan nilai-nilai humanisme religius

\section{Nilai-Nilai Humanisme Religius dalam Madrasah Inklusif}

Madrasah inklusif diselenggarakan dalam rangka mewujudkan hakhak asasi manusia untuk memperoleh pendidikan yang layak dan menghapus diskriminasi dalam pelayanan pendidikan. Dalam model pendidikan inklusif, lembaga pendidikan menyelenggarakan proses pembelajaran dengan tidak membeda-bedakan kemampuan peserta didik. Semua peserta didik akan diberikan pelayanan yang sesuai dengan kebutuhannya dengan model pendidikan yang universal dan menghilangkan kesenjangan-kesenjangan dalam memperoleh layanan pendidikan. Madrasah inklusif merupakan sarana dan prasarana yang difungsikan untuk memperkenalkan pendidikan universal yang akan

${ }^{26}$ Tim Kreatif, Al-Qur'an Terjemah Al-Ikhlas (Jakarta Pusat, SAMAD, 2014), 289. 
mampu mewujudkan madrasah yang respons terhadap keberagaman kemampuan dan kebutuhan peserta didik. ${ }^{27}$

Konsep pengembangan madrasah inklusif merupakan model pendidikan yang humanis religius. Pendidikan humanis religius adalah model pendidikan yang berbasis pada nilai-nilai dasar humanisme dan nilai-nilai religuisitas. Nilai-nilai dasar humanisme yaitu kemandirian, cinta terhadap sesama, cinta terhadap lingkungan, menghargai pendapat orang lain, kerjasama, kebebasan, kejujuran, kreativitas dan aktualisasi diri. Sedangkan nilai-nilai dasar religuisitas yaitu: pengetahuan (ilmu keagamaan), keimanan (aqidah), praktik keagamaan (syari'ah), pengamalan keagamaan (akhlak), dan penghayatan keagamaan (ma'rifat).28

Selain nilai-nilai humanisme dan religius yang terparikan di atas, menurut Adbdurrahman Mas'ud bahwa ada beberapa hal yang perlu dikembangkan dalam sebuah sistem pendidikan Islam seperti madrasah yaitu: common sense, akal sehat, kemandirian, thirst for knowlagde, pendidikan pluralism, kontekstualisme yang mengutamakan fungsi daripada lambang-lambang dan keseimbangan antara penghargaan dan hukuman. ${ }^{29}$. Berikut ini diagram dialektika dalam kajian humanisme relegius. ${ }^{30}$

${ }^{27}$ Sue Stubbs, Pendidikan Inklusif Ketika Hanya Ada Sedikit Sumber (The Atlas Alliance, 2002), 16-17.

${ }^{28}$ Ahmad Faqihuddin, "Internalisasi Nilai-Nilai Humanistik Relegius Pada Generasi Z Dengan Design For Change", Edukasia: Jurnal Penelitian Pendidikan Islam Vol. 12 No. 2, Agustus 2017.

${ }^{29}$ Abdurrahman Mas'ud, Menggagas Format Pendidikan, 154.

${ }^{30}$ Ibid., 154. 


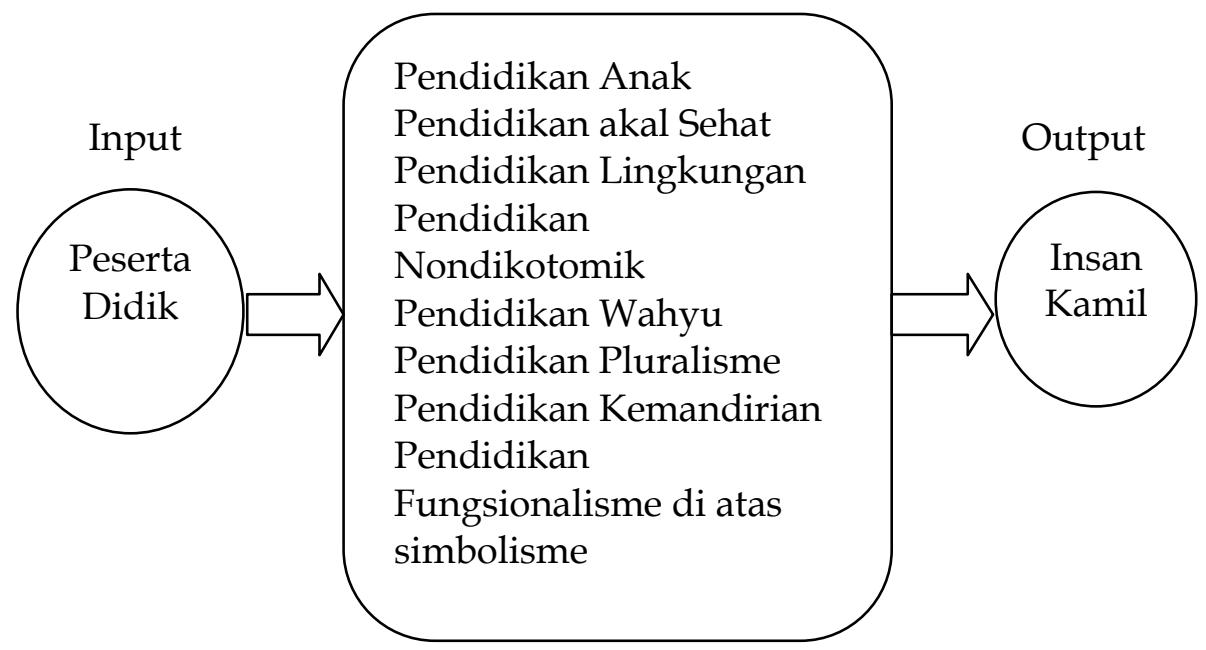

Bagan 1 Humanisme Relegius

\section{Model Pengembangan Kurikulum Madrasah Inklusif Berbasis Humanisme Religius}

Pendekatan humanisme dalam pengembangan kurikulum di madrasah inklusif maksudnya adalah mendesain kurikulum dengan memberikan kesempatan kepada peserta didik untuk mengaktualisasikan dirinya dalam proses pembelajaran serta menumbuhkan potensi-pontensi dasar yang dimiliki oleh peserta didik sesuai dengan fitrah manusia dan menjadikan peserta didik sebagai khalifah di muka bumi. ${ }^{31}$ Dengan pendekatan humanisme dalam desain kurikulum, maka peserta didik dalam proses pembelajaran merupakan subjek pendidikan (student centered), pendidik atau guru dalam proses pembelajaran diposisikan sebagai psikolog, motivator, konselor yang mampu memahami segala kebutuhan peserta didik dalam proses pembelajaran.

Penyusunan kurikulum madrasah dengan pendekatan humanisme melibatkan peserta didik dalam penentuan tujuan pembelajaran dan kompetensi yang ingin dicapai. Kurikulum yang diberlakukan adalah

31 Muhaimin, Pengembangan Kurikulum Pendidikan Agama Islam di Sekolah, Madrasah, dan Perguruan Tinggi, (Jakarta: PT Raja Grafindo Persada, 2005), 159-160. 
kurikulum minimal. Bahan ajar dan model proses pembelajarannya selalu berubah, disesuaikan dengan bakat, minat, dan kebutuhan peserta didik dan strategi pembelajaran yang dikembangan dalam model kurikulum humanism adalah active learning dengan mengedepankan prinsip-prinsip diantaranya adalah berpusat pada anak, mengembangkan kreativitas peserta didik, pembelajaran yang menantang dan menyenangkan, mengembangkan beragam kemampuan, menginternalisasikan nilai-nilai dalam pembelajaran, pengalaman belajar yang beragam dan learning to $\mathrm{do}^{32}$

Untuk mewujudkan desain kurikulum humanisme religius sebagaimana yang diuraikan di atas, maka terdapat beberapa model pengembangan kurikulum madrasah inklusif yaitu: model kurikulum duplikasi, model kurikulum modifikasi, model kurikulum subtitusi, model kurikulum omisi. ${ }^{33}$

Model duplikasi adalah memberlakukan kurikulum sesuai standar pendidikan nasional pada kelas inklusif yang terdiri dari peserta didik reguler dan peserta didik berkebutuhan khusus. Model duplikasi dalam implementasinya diterapkan pada peserta didik berkebutuhan khusus yang masih dapat mengikuti proses pembelajaran seperti peserti peserta didik reguler. Kompetensi dan tujuan yang akan dicapai oleh peserta didik berkebutuhan khusus sama dengan peserta didik reguler. Begitu pula model pembelajaran yang dipilih oleh seorang guru tanpa mengalami modifikasi.

Model modifikasi adalah desain kurikulum pada kelas inklusif yang disusun dengan memperhatikan kebutuhan peserta didik berkebutuhan khusus yaitu dengan memodifikasi bagian-bagian tertentu dalam kurikulum standar pendidikan nasional untuk disesuaikaan dengan bakat, minat dan kebutuhan ABK. Komponen-komponen yang dapat dimodifikasi adalah tujuan, isi atau materi pembelajaran, proses, dan evaluasi.

Model substitusi adalah model kurikulum humanisme pada madrasah inklusif dengan mengganti bagian-bagian tertentu yang terdapat pada kurikulum standar nasional dengan sesuatu yang lain dan sepadan dengan apa yang diganti atau memiliki nilai yang sama. Bagian-bagian yang dapat ganti meliputi isi, tujuan, materi, proses, dan evaluasi.

${ }^{32}$ Ibid., 161-163.

33 Zumrotul Mukaffa, Pengembangan Model Madrasah Inklusif (Studi atas Kesiapan dan Model Pengembangan Kurikulum Madrasah Inklusif, 10-11 
Model omisi yaitu desain kurikulum yang dalam implementasinya menghilangkan bagian-bagian tertentu atau keseluruannya dalam kurikulum standar nasional yang dikarenakan peserta didik berkebutuhan khusus tidak dapat mengikuti desain kurikulum yang ada. ${ }^{34}$

Keempat model kurikulum di atas dikembangkan setelah guru melakukan identifikasi dan assessment kepada peserta didik. Berikut ini contoh form identifikasi dan assessment untuk peserta didik tunanetra ${ }^{35}$.

\section{Tabel 1}

\section{ALAT IDENTIFIKASI ANAK BERKEBUTUHAN KHUSUS}

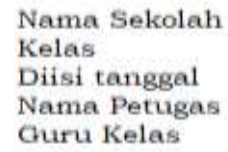

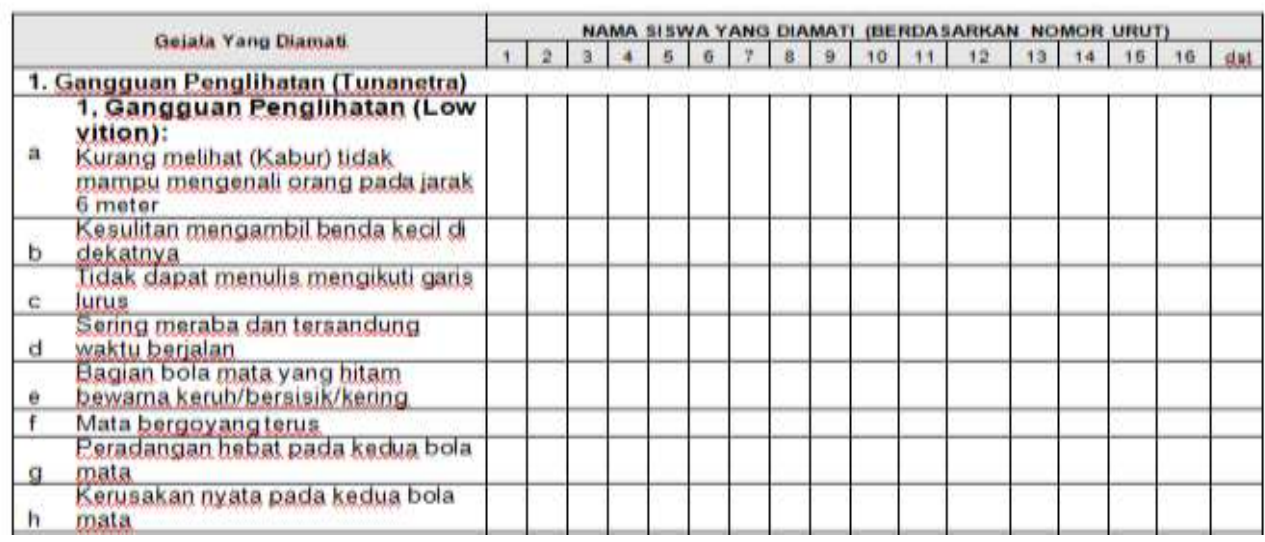

Setelah melakukan identifikasi dan assessment peserta didik, tahapan selanjutnya yaitu guru mendesain kurikulum dan perangkat pembelajaran dan PPI (Program Pembelajaran Individual) bagi peserta didik yang berkebutuhan khusus. Berikut ini model pengembangan kurikulum

${ }^{34}$ Ibid., 10-11.

${ }^{35}$ Deprtemen Pendidikan Nasional, Pedoman Khusus Penyelenggaraan Pendidikan Inklusif; Identifikasi Anak Berkebutuhan Khusus (Jakarta, Direktorat Jenderal Mendikdasmen Direktorat Pembinaan Sekolah Luar Biasa, 2007), 35. 
modifikasi dan omisi dalam madrasah inklusif dengan pendekatan humanism religius.

\section{Tabel 2}

Desain Pengembangan Kurikulum Inklusif dengan Pendekatan

Humanisme

\begin{tabular}{|c|c|c|c|c|c|c|c|c|}
\hline \begin{tabular}{|c|} 
Model \\
Kuriku-lum
\end{tabular} & $\begin{array}{c}\text { Sasaran } \\
\text { Kurikulum } \\
\text { Berdasarkan } \\
\text { assesment }\end{array}$ & $\begin{array}{c}\text { Metode } \\
\text { Pembela- } \\
\text { jaran }\end{array}$ & $\begin{array}{c}\text { Model } \\
\text { Penilai- } \\
\text { an }\end{array}$ & $\begin{array}{c}\text { Program } \\
\text { Layanan } \\
\text { Khusus }\end{array}$ & $\begin{array}{c}\text { Program } \\
\text { Penga- } \\
\text { yaan }\end{array}$ & $\begin{array}{c}\text { Program } \\
\text { Pengemba- } \\
\text { ngan bakat } \\
\text { istimewa }\end{array}$ & $\begin{array}{c}\text { Program } \\
\text { Intervensi } \\
\text { dengan } \\
\text { melibatkan } \\
\text { profesi ahli }\end{array}$ & $\begin{array}{c}\text { Program } \\
\text { Internalisa- } \\
\text { si nilai-nilai } \\
\text { humanisme } \\
\text { religius }\end{array}$ \\
\hline \begin{tabular}{|l|} 
Model \\
Modifikasi
\end{tabular} & $\begin{array}{l}\text { - Potensi } \\
\text { kecerdasasan } \\
\text { rata-rata } \\
\text { - Hambatan } \\
\text { non } \\
\text { akademia } \\
\text { ringan }\end{array}$ & $\begin{array}{l}\text { Klasikal } \\
\text { Kelompok } \\
\text { Individual }\end{array}$ & $\begin{array}{c}\text { Tes \& } \\
\text { Tes } \\
\text { Non }\end{array}$ & $\begin{array}{l}\text { Disesuai- } \\
\text { kan } \\
\text { dengan } \\
\text { jeni } \\
\text { ketunaan } \\
\text { serta } \\
\text { bakat dan } \\
\text { minat }\end{array}$ & $\begin{array}{l}\text { Tentatif } \\
\text { (jika } \\
\text { diperlu- } \\
\text { kan) }\end{array}$ & $\begin{array}{l}\text { Disesuikan } \\
\text { dengan } \\
\text { hasil } \\
\text { identifikasi } \\
\text { bakat dan } \\
\text { minat }\end{array}$ & $\begin{array}{l}\text { Disesuai- } \\
\text { kan dengan } \\
\text { kelainan } \\
\text { anak }\end{array}$ & $\begin{array}{l}\text { Kegiatan } \\
\text { pembiasan } \\
\text { di sekolah } \\
\text { dan di luar } \\
\text { sekolah }\end{array}$ \\
\hline $\begin{array}{l}\text { Model } \\
\text { Subsitusi }\end{array}$ & $\begin{array}{l}\text { - Anak dengan } \\
\text { bakat/cerdas } \\
\text { Istime } \\
\\
\text {-Potensi } \\
\text { kecerdasan } \\
\text { dibawah } \\
\text { rata-rata } \\
\text { kategori } \\
\text { ringan }\end{array}$ & $\begin{array}{l}\text { Klasikal } \\
\text { Kelompok } \\
\text { Individual }\end{array}$ & $\begin{array}{c}\text { Tes } \\
\text { \&Non } \\
\text { Tes }\end{array}$ & $\begin{array}{l}\text { Disesuai- } \\
\text { kan } \\
\text { dengan } \\
\text { jeni } \\
\text { ketunaan } \\
\text { serta } \\
\text { bakat dan } \\
\text { minat }\end{array}$ & Tentatif & $\begin{array}{l}\text { Disesuikan } \\
\text { dengan } \\
\text { hasil } \\
\text { identifikasi } \\
\text { bakat dan } \\
\text { minat }\end{array}$ & $\begin{array}{l}\text { Disesuai- } \\
\text { kan dengan } \\
\text { kelainan } \\
\text { anak }\end{array}$ & $\begin{array}{l}\text { Kegiatan } \\
\text { pembiasan } \\
\text { di sekolah } \\
\text { dan di luar } \\
\text { sekolah }\end{array}$ \\
\hline $\begin{array}{l}\text { Model } \\
\text { Omisi }\end{array}$ & $\begin{array}{l}\text { - Potensi } \\
\text { kecerdasan } \\
\text { di bawah } \\
\text { rata-rata } \\
\text { rendah }\end{array}$ & $\begin{array}{l}\text { Klasikal } \\
\text { Kelompok } \\
\text { Individual }\end{array}$ & $\begin{array}{l}\text { Tes \& } \\
\text { Non } \\
\text { Tes }\end{array}$ & $\begin{array}{l}\text { Disesuai- } \\
\text { kan } \\
\text { dengan } \\
\text { jeni } \\
\text { ketunaan } \\
\text { serta } \\
\text { bakat dan } \\
\text { minat }\end{array}$ & Tentatif & $\begin{array}{l}\text { Disesuikan } \\
\text { dengan } \\
\text { hasil } \\
\text { identifikasi } \\
\text { bakat dan } \\
\text { minat }\end{array}$ & $\begin{array}{l}\text { Disesuai- } \\
\text { kan dengan } \\
\text { kelainan } \\
\text { anak }\end{array}$ & $\begin{array}{l}\text { Kegiatan } \\
\text { pembiasan } \\
\text { di sekolah } \\
\text { dan di luar } \\
\text { sekolah }\end{array}$ \\
\hline
\end{tabular}

Berdasarkan tabel desain pengembangan kurikulum inklusif dengan pendekatan humanisme di atas, model pengembangan perencanaan pembelajaran individual (PPI) yang dapat dikembangkan sebagai berikut. 


\section{PROGRAM PEMBELAJARAN INDIVIDU (PPI)}

\section{A. Informasi Siwa}
1. Nama
: AG
2. Tempat,Tgl Lahir : Surabaya, 7-10-2010
3. Nama Orangtua : BA
4. Alamat
: Surabaya
5. Sekolah
:SDN 1 Surabaya
6. Kelas
$: 2$

B. Kekhususan : Utama/Primer : Autisme

Tambahan/Sekunder : Gangguan/konsentrasi

C. Penempatan : (Berasal dari asessmen lalu dimasukkan dalam My Profil)

$\checkmark$ Dalam kelas regular bersama dengan siswa lain selama 6 hari

$\checkmark$ Pelaksanaan secara individual (terpisah dari yang lain) yaitu satu jam dalam sehari setelah KBM pada hari Senin dan Kamis.

D. Standar Kurikulum : Standar Sekolah

E. Data Asessmen

\begin{tabular}{|c|c|c|}
\hline $\begin{array}{l}\text { Sumber } \\
\text { Informasi }\end{array}$ & Waktu & Ringkasan Hasil \\
\hline $\begin{array}{l}\text { Guru } \\
\text { Pembimbing } \\
\text { Khusus }\end{array}$ & September & $\begin{aligned} & \text { Afektif: } \\
& \checkmark \text { Siswa masih memerlukan } \\
& \text { bimbingan dalam mengucapkan } \\
& \text { salam, dan bersalaman dengan } \\
& \text { guru ketika datang ke sekolah. } \\
& \checkmark \text { Siswa masih sering terlambat ke } \\
& \text { sekolah. } \\
& \checkmark \text { Siswa belum bisa menyelesaikan } \\
& \text { tugas sesuai dengan waktu yang } \\
& \text { diberikan. } \\
& \checkmark \text { Siswa masih memerlukan } \\
& \text { bimbingan dalam memakai sepatu. } \\
& \text { Motorik: } \\
& \checkmark \quad \text { Untuk motoriknya memerlukan } \\
& \text { arahan. }\end{aligned}$ \\
\hline
\end{tabular}




\begin{tabular}{|c|c|c|}
\hline & & $\begin{array}{ll}\text { Kognitif: } \\
\checkmark & \text { Masih sangat lamban sehingga } \\
& \text { memerlukan bimbingan serta } \\
& \text { arahan lebih dan khusus. } \\
\checkmark & \text { Belum memahami pertanyaan dan } \\
& \text { perintah terlebih yang } \\
& \text { berhubungan dengan perintah } \\
& \text { tertulis. } \\
\checkmark & \text { Masih mengulang pertanyaan } \\
& \text { yang diberikan. } \\
\checkmark & \text { Masih kesulitan dalam melakukan } \\
& \text { komunikasi dua arah (lebih } \\
\text { cenderung memakai gesture atau } \\
\text { kata-kata yang hanya bisa } \\
\text { dipahami oleh orang terdekat } \\
\text { dalam mengungkapkan } \\
\text { keinginan). } \\
\checkmark \text { Konsentrasinya masih sangat } \\
\text { kurang saat belajar maupun saat } \\
\text { diajak berkomunikasi. } \\
\checkmark & \text { Lebih sering mengungkapkan } \\
\text { kata/kalimat iklan daripada } \\
\text { kata/kalimat untuk } \\
\text { berkomunikasi. }\end{array}$ \\
\hline Guru Kelas & September & $\begin{array}{ll}\checkmark & \text { Pasif dalam proses belajar di kelas } \\
\checkmark & \text { Belum dapat berinteraksi secara } \\
\text { mandiri dengan teman ataupun } \\
\text { guru. } \\
\checkmark \quad \text { Tugas sekolah maupun tugas } \\
\text { rumah dibantu oleh ibunya. }\end{array}$ \\
\hline Guru Penjaskes & September & $\begin{array}{l}\text { Ananda dapat mengikuti olah } \\
\text { raga dengan baik melalui contoh } \\
\text { gerakan dari guru. }\end{array}$ \\
\hline Wali Siswa & Juli & $\begin{array}{ll}\checkmark & \text { Dapat membaca kata serta } \\
\text { kalimat. } \\
\checkmark \quad \text { Dapat duduk tenang saat dalam } \\
\text { proses belajar ketika didampingi. } \\
\checkmark \quad \text { Masih mengulang pertanyaan } \\
\checkmark \text { yang diberikan. } \\
\checkmark \text { Belum memahami pertanyaan dan }\end{array}$ \\
\hline
\end{tabular}




\begin{tabular}{|l|l|l|}
\hline & & perintah terlebih yang \\
& berhubungan dengan perintah \\
& tertulis. \\
$\checkmark$ & Masih belum bisa bermain dengan \\
& teman sebaya (asyik bermain \\
& permainan sendiri) \\
$\checkmark$ & Konsentrasinya masih kurang saat \\
& belajar maupun saat diajak \\
& berkomunikasi. \\
$\checkmark$ & Lebih sering mengungkapkan \\
& kata/kalimat iklan daripada kata/ \\
& kalimat untuk berkomunikasi. \\
$\checkmark$ & Penekanan saat menulis belum \\
kuat (mantap) & Kemandirian dalam mengerjakan \\
$\checkmark$ & tugas masih membututhkan \\
& latihan. \\
\hline
\end{tabular}

F. Kekuatan dan Kelemahan Siswa

\begin{tabular}{|l|ll|}
\hline \multicolumn{1}{|c|}{ Kekuatan } & \multicolumn{1}{c|}{ Kelemahan } \\
$\checkmark \begin{array}{l}\text { Dapat membaca kata serta } \\
\text { kalimat. }\end{array}$ & $\checkmark$ & $\begin{array}{l}\text { Masih mengulang pertanyaan } \\
\text { yang diberikan. }\end{array}$ \\
$\begin{array}{l}\text { Mampu menulis dikte dengan } \\
\text { baik. }\end{array}$ & $\checkmark$ & $\begin{array}{l}\text { Belum memahami pertanyaan } \\
\text { dan perintah terlebih yang } \\
\text { berhubungan dengan perintah } \\
\text { Dapat mengikuti intruksi atau } \\
\text { perintah pendek. }\end{array}$ \\
$\begin{array}{l}\text { Dapat duduk tenang saat } \\
\text { dalam proses belajar ketika } \\
\text { didampingi. }\end{array}$ & $\checkmark \begin{array}{l}\text { Masih kesulitan dalam } \\
\text { melakukan komunikasi dua arah } \\
\text { (lebih cenderung memakai }\end{array}$ \\
& $\begin{array}{l}\text { gesture atau kata-kata yang } \\
\text { hanya bisa dipahami oleh orang } \\
\text { terdekat dalam mengungkapkan } \\
\text { keinginan). }\end{array}$ \\
& $\checkmark \begin{array}{l}\text { Masih belum bisa bermain } \\
\text { dengan teman sebaya (asyik } \\
\text { bermain permainan sendiri) }\end{array}$ \\
& $\checkmark \begin{array}{l}\text { Konsentrasinya masih kurang } \\
\text { ketika belajar maupun saat diajak } \\
\text { berkomunikasi. }\end{array}$ \\
\hline
\end{tabular}




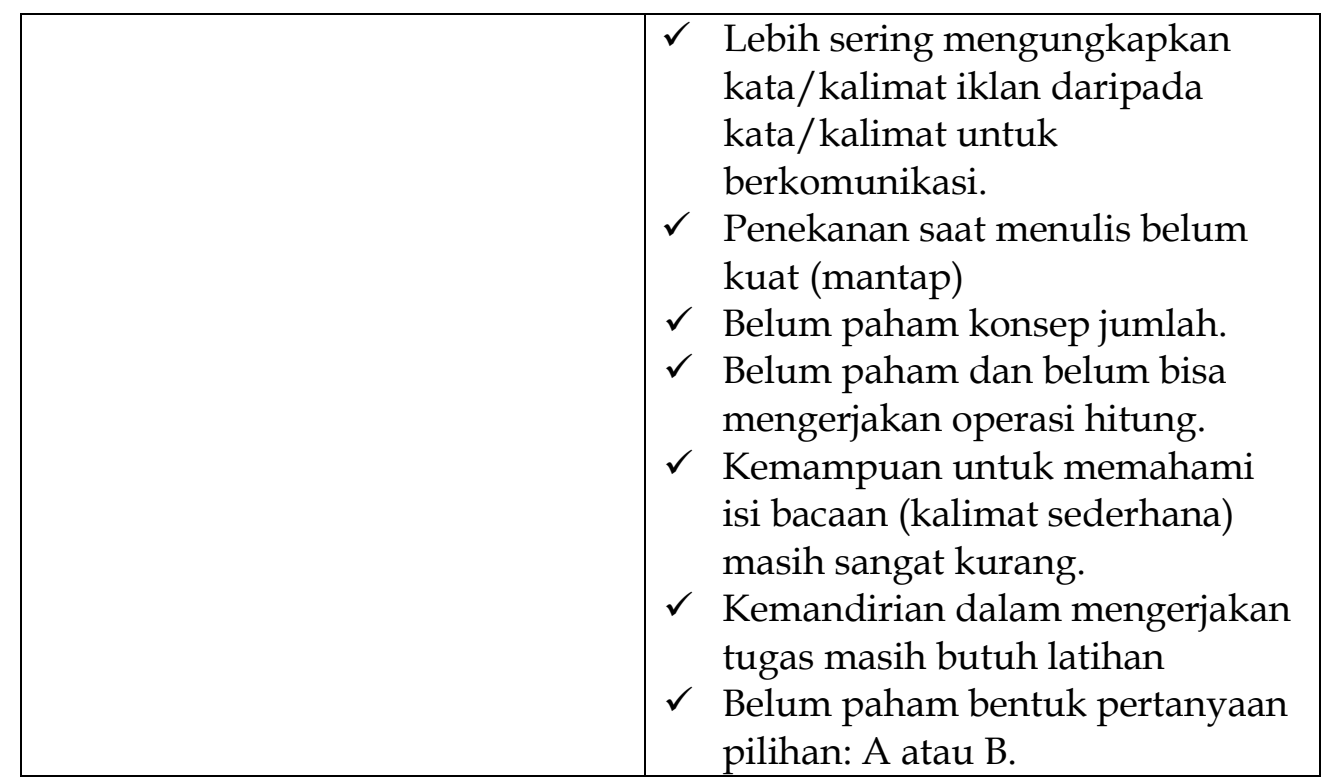

\section{G. Mata Pelajaran Atau Keterampilan Kompensatoris}

$\checkmark$ MCA : Penyesuaian dalam menggunakan metode/cara/alat/ bahan/tanpa merubah isi kurikulum.

$\checkmark$ IK : Penyesuaian terutama dalam materi, isi kurikulum.

$\checkmark$ GAB : Penyesuaian dilaksanakan dalam hal isi atau metode/ cara/alat secara bersamaan atau bergantian.

\begin{tabular}{|c|l|c|c|c|}
\hline \multirow{2}{*}{ No } & \multicolumn{1}{|c|}{ Mata Pelajaran } & \multicolumn{3}{c|}{ Penyesuaian } \\
\hline & & MCA & IK & GAB \\
\hline 1. & Bahasa Indonesia & & & $\checkmark$ \\
\hline 2. & Matematika & & & $\checkmark$ \\
\hline 3. & IPS & & & $\checkmark$ \\
\hline 4. & IPA & & & $\checkmark$ \\
\hline 5. & Bhs. Jawa & & & $\checkmark$ \\
\hline 6. & TIK & $\checkmark$ & & \\
\hline 7. & Kesenian & $\checkmark$ & & \\
\hline 8. & Penjaskes & & & $\checkmark$ \\
\hline 9. & Bina & & & $\checkmark$ \\
\hline 10. & Keterampilan Berkomunikasi & & & \\
\hline
\end{tabular}




\section{Kebutuhan}

\begin{tabular}{|l|l|}
\hline \multicolumn{1}{|c|}{ Alat } & \multicolumn{1}{c|}{ Penyesuaian } \\
\hline Media Gambar & Di dampingi oleh shadow saat KBM. \\
\hline Kartu huruf dan Angka & $\begin{array}{l}\text { Pada waktu KBM tempat duduk didekatkan } \\
\text { dengan guru. }\end{array}$ \\
\hline Kartu Kata & $\begin{array}{l}\text { Memberikan sentuhan dengan membantu } \\
\text { mengerakkan jari tangan untuk menulis. }\end{array}$ \\
\cline { 2 - 2 } & $\begin{array}{l}\text { Memberikan reward atau penghargaan berupa } \\
\text { kata pujian atau melakukan tos pada saat } \\
\text { dapat menyelesaikan satu tugas. }\end{array}$ \\
\hline & $\begin{array}{l}\text { Memberikan semnangat dan motivasi dalam } \\
\text { belajar. }\end{array}$ \\
\hline
\end{tabular}

\section{H. Program Layanan Kebutuhan Khusus/Kompensatoris}

1. Keterampilan Afektif / Sikap (Proses Pembentukan Karakter Siswa)

Based Line:

$\checkmark$ Siswa masih memerlukan bimbingan dalam mengucapkan salam, dan bersalaman dengan guru ketika datang ke sekolah.

$\checkmark$ Siswa masih sering terlambat ke sekolah.

$\checkmark$ Siswa belum bisa menyelesaikan tugas sesuai dengan waktu yang diberikan.

$\checkmark$ Siswa masih memerlukan bimbingan dalam memakai sepatu.

Indikator keberhasilan pada akhir semester:

$\checkmark$ Siswa mampu mengucapkan salam dan bersalaman dengan guru secara mandiri.

$\checkmark \quad$ Siswa tidak terlambat masuk sekolah.

$\checkmark$ Siswa mampu myelesaikan tugas tepat waktu.

$\checkmark$ Siswa mampu memakai sepatu secara mandiri. 


\section{Pembelajaran Dilaksanakan dalam Kelas Regular dan Ruang Sumber}

\begin{tabular}{|c|c|c|c|}
\hline $\begin{array}{c}\text { Tujuan } \\
\text { Pembelajaran }\end{array}$ & $\begin{array}{c}\text { Karakter } \\
\text { yang di } \\
\text { terapkan }\end{array}$ & $\begin{array}{c}\text { Strategi } \\
\text { Pembelajaran }\end{array}$ & $\begin{array}{l}\text { Teknik/Alat } \\
\text { Penilaian }\end{array}$ \\
\hline $\begin{array}{l}\text { Satu Semester } \\
\text { Tahap 1 } \\
\text { Siswa mampu } \\
\text { mengucapkan } \\
\text { salam dan } \\
\text { bersalaman } \\
\text { dengan guru } \\
\text { secara mandiri }\end{array}$ & Religius & $\begin{array}{l}\text { Pembiasaan siswa } \\
\text { mengucapkan salam } \\
\text { dan bersalaman pada } \\
\text { waktu datang dan } \\
\text { pulang sekolah }\end{array}$ & Demonstrasi \\
\hline $\begin{array}{l}\text { Tahap } 2 \\
\text { Siswa tidak } \\
\text { terlambat masuk } \\
\text { sekolah }\end{array}$ & $\begin{array}{l}\text { Disiplin \& } \\
\text { tanggung } \\
\text { jawab }\end{array}$ & $\begin{array}{l}\text { Pemberian reward } \\
\text { stiker ketika siswa } \\
\text { tidak terlambat }\end{array}$ & Demonstrasi \\
\hline $\begin{array}{l}\text { Tahap } 3 \\
\text { Siswa mampu } \\
\text { meyelesaikan } \\
\text { tugas tepat } \\
\text { waktu }\end{array}$ & Disiplin & $\begin{array}{l}\text { Pemberian reward } \\
\text { berupa kesempatan } \\
\text { untuk membaca } \\
\text { Koran yang menjadi } \\
\text { kesenangan siswa, } \\
\text { ketika siswa berhasil } \\
\text { menyelesaikan tugas } \\
\text { tepat waktu. }\end{array}$ & Tes tulis \\
\hline $\begin{array}{l}\text { Tahap } 4 \\
\text { Siswa mampu } \\
\text { memakai sepatu } \\
\text { secara mandiri }\end{array}$ & Mandiri & $\begin{array}{l}\text { Pembiasaan melatih } \\
\text { siswa memakai } \\
\text { sepatu sendiri pada } \\
\text { saat pulang sekolah } \\
\text { yang dilakukan terus } \\
\text { menerus oleh guru. }\end{array}$ & Demonstrasi \\
\hline
\end{tabular}




\section{Keterampilan Berkomunikasi}

\section{Based Lines:}

$\checkmark$ Perintah yang agak panjang harus diulang 2 sampai 3 kali.

$\checkmark$ Masih kesulitan untuk menyampaikan kata-kata/jawaban.

$\checkmark$ Tidak terlalu memahami arti / maksud dari pernyataan yang diberikan.

$\checkmark$ Tidak ada kata-kata yang diucapkan jika tidak dengan bantuan atau diajak bicara.

$\checkmark$ Pengucapan kata dan kalimat iklan yang terlalu sering.

\section{Indikator Keberhasilan Pada Akhir Semester:}

$\checkmark$ Tidak kesulitan memilih kata-kata yang tepat untuk menyampaikan maksud.

$\checkmark$ Dapat mengerti kata yang disampaikan orang lain.

$\checkmark$ Dapat terlibat dalam pembicaraan sesuai dengan apa yang sedang dibicarakan (nyambung).

$\checkmark$ Tidak ada kata-kata yang masih diucapkan.

$\checkmark$ Tidak ada kata dan kalimat iklan yang diucapkan (membeo).

Pembelajaran Dilaksanakan dalam Kelas Regular dan Ruang Sumber Uraian Kegiatan

\begin{tabular}{|c|c|c|c|}
\hline $\begin{array}{c}\text { Tujuan } \\
\text { Pembelajaran }\end{array}$ & $\begin{array}{c}\text { Nilai } \\
\text { Humanisme } \\
\text { Relegius yang } \\
\text { dikembangkan }\end{array}$ & $\begin{array}{c}\text { Strategi } \\
\text { Pembelajaran }\end{array}$ & $\begin{array}{c}\text { Teknik/Alat } \\
\text { Penilaian }\end{array}$ \\
\hline $\begin{array}{l}\text { Satu Semester } \\
\text { Tahap } 1 \\
\text { Siswa tidak } \\
\text { kesulitan } \\
\text { memilih kata- } \\
\text { kata yang tepat } \\
\text { untuk } \\
\text { menyampaikan } \\
\text { maksudnya. }\end{array}$ & $\begin{array}{l}\text { Mandiri \& } \\
\text { Peduli Sosial }\end{array}$ & $\begin{array}{l}\text { Member waktu } \\
\text { yang lebih untuk } \\
\text { dapat } \\
\text { menceritakan } \\
\text { pengalaman } \\
\text { pribadinya } \\
\text { sehari-hari. }\end{array}$ & $\checkmark \quad$ Tes lisan \\
\hline
\end{tabular}




\begin{tabular}{|c|c|c|c|}
\hline $\begin{array}{l}\text { Tahap } 2 \\
\text { Sisiwa dapat } \\
\text { mengerti arti } \\
\text { kata yang } \\
\text { disampaikan } \\
\text { orang lain. }\end{array}$ & $\begin{array}{c}\text { Mandiri \& } \\
\text { Peduli Sosial }\end{array}$ & $\begin{array}{l}\text { Pemberian } \\
\text { perintah atau } \\
\text { soal yang } \\
\text { sederhana } \\
\text { dengan kata } \\
\text { kerja operasional } \\
\text { sesuai dengna } \\
\text { karakteristik } \\
\text { obyek (mata } \\
\text { pelajaran) }\end{array}$ & $\begin{array}{ll}\checkmark & \text { Tes lisan } \\
\checkmark & \text { Demonstrasi }\end{array}$ \\
\hline $\begin{array}{l}\text { Tahap } 3 \\
\text { Siswa dapat } \\
\text { terlibat dalam } \\
\text { pembicaraan } \\
\text { sesuai dengan } \\
\text { apa yang } \\
\text { sedang } \\
\text { dibicarakan } \\
\text { (nyambung). }\end{array}$ & $\begin{array}{l}\text { Mandiri \& } \\
\text { Peduli Sosial }\end{array}$ & $\begin{array}{l}\text { Komunikasi } \\
\text { dilakukan secara } \\
\text { vokasional dan } \\
\text { dua arah antar } \\
\text { guru dengan } \\
\text { siswa atau GPK } \\
\text { dengan siswa. }\end{array}$ & $\begin{array}{ll}\checkmark & \text { Tes lisan } \\
\checkmark & \text { Demonstrasi }\end{array}$ \\
\hline $\begin{array}{l}\text { Tahap } 4 \\
\text { Siswa tidak ada } \\
\text { kata-kata yang } \\
\text { masih salah } \\
\text { diucapkan dan } \\
\text { tidak membeo } \\
\text { kata dan } \\
\text { kalimat lain. }\end{array}$ & $\begin{array}{l}\text { Mandiri \& } \\
\text { Peduli Sosial }\end{array}$ & $\begin{array}{l}\text { Drilling } \\
\text { dalam } \\
\text { menunjukkan } \\
\text { dan } \\
\text { menyebutkan } \\
\text { nama-nama } \\
\text { benda konkrit } \\
\text { ataupun } \\
\text { gambar. } \\
\checkmark \text { Drilling } \\
\text { dalam } \\
\text { menyebutkan } \\
\text { kata kerja } \\
\text { dengan } \\
\text { melihat } \\
\text { gambar } \\
\text { aktivitas } \\
\text { seseorang }\end{array}$ & $\begin{array}{ll}\checkmark & \text { Tes lisan } \\
\checkmark & \text { Demonstrasi }\end{array}$ \\
\hline
\end{tabular}




\section{Keterampilan Akademik}

\subsection{Based Line:(Menulis)}

$\checkmark$ Mencontoh kalimat sederhana berpola SPOK masih kurang, karena tulisan masih terlalu besar dan tidak rapi.

\section{Indikator Keberhasilan Pada Akhir Semester:}

$\checkmark$ Mampu mencontoh kalimat sederhana (SPOK) dengan baik dan rapi.

Pembelajaran Dilaksanakan dalam Kelas Regular dan Ruang Sumber Uraian Kegiatan

\begin{tabular}{|c|c|c|c|}
\hline $\begin{array}{c}\text { Tujuan } \\
\text { Pembelajaran }\end{array}$ & $\begin{array}{c}\text { Nilai } \\
\text { Humanisme- } \\
\text { Relegius yang } \\
\text { dikembangkan }\end{array}$ & $\begin{array}{c}\text { Strategi } \\
\text { Pembelajaran }\end{array}$ & $\begin{array}{c}\text { Teknik/ Alat } \\
\text { Penilaian }\end{array}$ \\
\hline $\begin{array}{l}\text { Siswa mampu } \\
\text { mencontoh } \\
\text { kalimat } \\
\text { sederhana } \\
\text { (SPOK) }\end{array}$ & $\begin{array}{l}\text { Mandiri, } \\
\text { kejujuran, } \\
\text { tolong- } \\
\text { menolong }\end{array}$ & $\begin{array}{l}\text { Menuliskan } \\
\text { kembali kalimat } \\
\text { sederhana yang } \\
\text { dicontohkan } \\
\text { dalam buku oleh } \\
\text { guru dengan } \\
\text { memberi variasi } \\
\text { warna pada } \\
\text { setiap kata yang } \\
\text { dituliskan. } \\
\checkmark \text { Menuliskan } \\
\text { kembali kalimat } \\
\text { sederhana yang } \\
\text { dicontohkan } \\
\text { dipapan tulis } \\
\text { oleh guru untuk } \\
\text { ditulis dalam } \\
\text { buku. }\end{array}$ & $\begin{array}{ll}\checkmark & \text { Tes lisan } \\
\checkmark & \text { Tes tulis } \\
\checkmark & \text { Non tes }\end{array}$ \\
\hline
\end{tabular}

\subsection{Based Line: (Berhitung)}

$\checkmark$ Belum memahami konsep jumlah

$\checkmark$ Belum mampu mengerjakan operasi hitung

\section{Indikator Keberhasilan Pada Akhir Semester:}

$\checkmark$ Mampu memahami konsep jumlah

$\checkmark$ Mampu mengerjakan operasi hitung 
Pembelajaran Dilaksanakan dalam Kelas Regular dan Ruang Sumber

Uraian Kegiatan

\begin{tabular}{|c|c|c|c|}
\hline $\begin{array}{c}\text { Tujuan } \\
\text { Pembelajaran }\end{array}$ & $\begin{array}{c}\text { Nilai } \\
\text { Humanisme } \\
\text { Relegius yang } \\
\text { dikembangkan }\end{array}$ & $\begin{array}{c}\text { Strategi } \\
\text { Pembelajaran }\end{array}$ & $\begin{array}{c}\text { Teknik/ Alat } \\
\text { Penilaian }\end{array}$ \\
\hline $\begin{array}{l}\text { Tahap } 1 \\
\text { Siswa dapat } \\
\text { memahami } \\
\text { konsep jumlah }\end{array}$ & Mandiri & $\begin{array}{ll}\checkmark \text { Drilling } \\
\text { menunjukkan } \\
\text { gambar benda } \\
\text { dan kartu } \\
\text { angka } \\
\checkmark & \text { Drilling } \\
& \text { menghitung } \\
\text { jumlah gambar } & \text { dan benda. }\end{array}$ & $\begin{array}{ll}\checkmark & \text { Tes lisan } \\
\checkmark & \text { Demonstrasi }\end{array}$ \\
\hline $\begin{array}{l}\text { Tahap } 2 \\
\text { Siswa dapat } \\
\text { mengerjakan } \\
\text { operasi hitung } \\
\text { penjumlahan }\end{array}$ & Mandiri & $\begin{aligned} \checkmark & \text { Drilling } \\
& \text { menunjukkan } \\
& \text { simbol dari } \\
& \text { penjumlahan } \\
\checkmark & \text { Drilling } \\
& \text { pemahaman } \\
& \text { konsep } \\
& \text { penjumlahan }\end{aligned}$ & $\begin{array}{ll}\checkmark & \text { Tes lisan } \\
\checkmark & \text { Demonstrasi }\end{array}$ \\
\hline $\begin{array}{l}\text { Tahap } 3 \\
\text { Siswa dapat } \\
\text { mengerjakan } \\
\text { operasi hitung } \\
\text { pengurangan. }\end{array}$ & Mandiri & $\begin{array}{ll}\checkmark & \text { Drilling } \\
& \text { menunjukkan } \\
& \text { simbol } \\
& \text { pengurangan. } \\
\checkmark & \text { Drilling } \\
& \text { pemahaman } \\
& \text { konsep operasi } \\
& \text { pengurangan } \\
\end{array}$ & $\begin{array}{ll}\checkmark & \text { Tes lisan } \\
\checkmark & \text { Demonstrasi }\end{array}$ \\
\hline
\end{tabular}


Personal Yang Terlibat

\begin{tabular}{|l|c|c|}
\hline \multicolumn{1}{|c|}{ Jenis Pelayanan } & \multicolumn{1}{c|}{ Frekuensi } & Lokasi \\
\hline $\begin{array}{l}\text { Klasikal / Reguler } \\
\text { dengan guru kelas dan } \\
\text { GPK }\end{array}$ & Setiap hari dalam KBM & $\begin{array}{c}\text { Ruang kelas dan } \\
\text { lingkungan sekolah }\end{array}$ \\
\hline Individu dengan GPK & $\begin{array}{c}\text { 1 jam dalam sehari } \\
\text { setelah KBM pada hari } \\
\text { selasa dan kamis }\end{array}$ & $\begin{array}{c}\text { Ruang sumber dan } \\
\text { lingkungan sekolah }\end{array}$ \\
\hline
\end{tabular}

\section{Kesimpulan}

Madrasah Inklusif adalah lembaga pendidikan yang menyelenggarakan pendidikan dengan model menyatukan peserta didik reguler dengan peserta didik berkebutuhan khusus dalam satu lingkungan pendidikan. Melalui model pendidikan tersebut, konsep madrasah inklusif mampu menginternalisasikan nillai-nillai humanisme relegius dalam proses pembelajaran di dalam kelas maupun di luar kelas. Secara implementatif, proses internalisasi nilai-nilai humanisme relegius dituangkan dalam desain kurikulum madrasah inklusif dan desain perancanaan pembelajaran. Melalui pendekatan humanisme relegius dalam pengembangan kurikulum, peserta didik diharapkan mampu hidup mengembangkan potensi dirinya dalam rangka mewujudkan sifat-sifat ketuhanan (fitrah) dalam kehidupan sehari-hari sehingga terwujud insan kamil. 


\section{DAFTAR PUSTAKA}

Amin, Husna. "Aktualisasi Humanisme Relegius Menuju Humanisme Spiritual dalam Bingkai Filsafat Agama" Jurnal Substantia Vol. XV, No. 1 April 2013.

Atabik Lutfi, Ahmad Zuhdi Muhdlor, Kamus Kontemporer Arab-Indonesia, Yogyakarta: Yayasan Ali Maksum Ponpes Krapyak Yogyakarta, 1997.

Farida, Yushinta Eka. "Humanisme Dalam Pendidikan Islam" Jurnal Tarbawi Vol. 12 No. 1. Januari-Juni 2015.

Faqihuddin, Ahmad. "Internalisasi Nilai-Nilai Humanistik Relegius Pada Generasi Z Dengan Design For Change", Edukasia: Jurnal Penelitian Pendidikan Islam Vol. 12 No. 2, Agustus 2017.

Idi, Abdullah. 1999. Pengembangan Kurikulum Teori dan Praktek. Jakarta: Gaya Media Pratama.

Idris Thaha. 2005. al-Madrasah dalam Ensiklopedi Islam, Vol. 3. Jakarta: Ichtiar Baru Van Hoeve.

Mas'ud, Abdurrahman. 2002. Menggagas Format Pendidikan Nondikotomik (Humanisme Religius Sebagai Peradigma Pendidikan Islam). Yogyakarta: Gama Media.

Mukaffa, Zumrotul dkk. Pengembangan Model Madrasah Inklusif (Studi atas Kesiapan dan Model Pengembangan Kurikulum Madrasah Inklusif MI Al-Hidayah Margorejo Surabaya) EDUKASIA: Jurnal Penelitian Pendidikan Islam, Vol 12, No 1 (2017). http://digilib.uinsby.ac.id

Muhaimin. 2005. Pengembangan Kurikulum Pendidikan Agama Islam di Sekolah, Madrasah, dan Perguruan Tinggi. Jakarta: Raja Grafindo Persada. 
Muzayanah, Umi. “Penyelenggaraan Pendidikan Inklusif Pada Madrasah Ibtidaiyah (MI) Keji Ungaran Jawa Tengah" PENAMAS “Jurnal Keagamaan dan Kemasyarakatan" Volume 29, Nomor 2 JuliSeptember 2016.

Rohmadi, Syamsul Huda. Kurikulum Berbasis Inklusif di Madrasah (Landasan Teori dan Desain Pembelajaran Prespektif Islam), digilib.uinsby.ac.i.

Stubbs, Sue. 2002. Pendidikan Inklusif Ketika Hanya Ada Sedikit Sumber. The Atlas Alliance.

Tim Kreatif, Al-Qur'an Terjemah Al-Ikhlas. Jakarta Pusat, SAMAD, 2014.

Wehr, Hans. 1980. A Dictionary of Modern Written Arabic. ed. J Milton Cowan. Beirut: Maktabah Lubnan.

Yasin, A. Fatah. 2008. Dimensi-Dimensi Pendidikan Islam. Malang: UIM Malang Press.

Direktorat Pembinaan Sekolah Luar Biasa. 2008. Pedoman Manajemen Sekolah Inklusif Pendidikan Dasar. Jakarta, Departemen Pendidikan Nasional.

Departemen Pendidikan Nasional. 2007. Pedoman Khusus Penyelenggaraan Pendidikan Inklusif; Identifikasi Anak Berkebutuhan Khusus . Jakarta, Direktorat Jenderal Mendikdasmen Direktorat Pembinaan Sekolah Luar Biasa.

Undang-Undang Republik Indonesia Nomor 20 Tahun 2003 Tentang Sistem Pendidikan Nasional, 4. http://kelembagaan.ristekdikti. go.id/wp-

Peraturan Menteri Pendidikan dan Kebudayaan Republik Indonesia Nomor 23 Tahun 2016 tentang Standar Penilaian Pendidikan.

Peraturan Menteri Pendidikan Nasional Republik Indonesia Nomor 24 Tahun 2007 tentang Standar Sarana dan Prasarana SD/MI/SMP/MTs, SMA/ MA 
Peraturan Menteri Pendidikan dan Kebudayaan Republik Indonesia Nomor 23 Tahun 2016 tentang Standar penilaian Pendidikan

Peraturan Menteri Pendidikan Nasional Republik Indonesia Nomor 24 Tahun 2007 tentang Standar Sarana dan Prasarana SD/MI/SMP/MTs, SMA/ MA.

Peraturan Menteri Agama Republik Indonesia Nomor 90 Tahun 2013 tentang Penyelenggaraan Pendidikan Madrasah.

Permendikbud Nomor 70 tahun 2009 tentang Pendidikan, Inklusif Bagi Peserta Didik Yang Memiliki Kelainan dan Memiliki Potensi Kecerdasan dan/atau Bakat Istimewa.

Undang-Undang Republik Indonesia Nomor 20 Tahun 2003 Tentang Sistem Pendidikan Nasional, 4. http://kelembagaan.ristekdikti. go.id/wp- 